\title{
EFEK SUHU LINGKUNGAN TERHADAP FISIOLOGI TUBUH PADA SAAT MELAKUKAN LATIHAN OLAHRAGA
}

\author{
Edy Mintarto ${ }^{1}$, Muhammad Fattahilah ${ }^{2}$ \\ 12 Jurusan Pendidikan Kepelatihan Olahraga, Universitas Negeri Surabaya, Surabaya, Indonesia \\ *edymintarto@unesa.ac.id
}

(Received: February 2019 / Revised: March 2019 / Accepted: March 2019)

ABSTRAK: Peningkatan suhu lingkungan berpengaruh terhadap performa tubuh pada saat melakukan aktifitas olahraga. Suhu lingkungan yang terlalu rendah $\left(10^{\circ}+1{ }^{\circ} \mathrm{C}\right)$ dan terlalu tinggi $\left(37^{\circ} \mathrm{C}\right) \mathrm{mampu}$ meningkatkan kadar asam laktat lebih tinggi, serta proses oxygen intake (VO2Max) yang kurang optimal. Pada suhu ruangan tinggi, tubuh mengalami peningkatan suhu tubuh lebih tinggi dan dan tekanan terhadap kardiovaskuler lebih tinggi sehingga mengakibatkan proses dehidrasi lebih tinggi sebagai bentuk perlawanan terhadap peningkatan suhu tersebut. Proses review dilakukan untuk mengetahui dari berbagai sumber dan mengumpulkan data-data yang memiliki keterkaitan dengan kondisi lingkungan dan tubuh saat latihan. Indikator yang banyak disebut dalam penelitian ialah kondisi kandungan pada cairan ludah, suhu tubuh, komposisi cairan tubuh dan tingkatan kandungan asam laktat. Suhu lingkungan optimal yang dianjurkan pada saat melakukan aktifitas olahraga yaitu berada pada kisaran $20^{\circ}-23^{\circ}$ Celcius.

KATA KUNCI: Suhu Lingkungan, Suhu Tubuh, Performa, Olahraga.

ABSTRACTS: Increasing the ambient temperature affects the body's performance when doing sports activities. The ambient temperature is low $\left(10^{\circ}+1^{\circ} \mathrm{C}\right)$ and high $\left(37^{\circ} \mathrm{C}\right)$ getting increase lactic acid levels and the oxygen intake (VO2Max) is less optimal. At high temperatures, the body increase temperature and cardiovascular pressure resulting in a higher dehydration process as a form of resistance to the increase in temperature. The recommended optimal environmental temperature during sports activities is in the range of $20^{\circ}-23^{\circ} \mathrm{C}$.

KEYWORD: $\quad$ Environmental Temperature, Body Temperature, Performance, Sports.

\section{PENDAHULUAN}

Berolahraga selama ini dilakukan hanya dengan berpedoman pada tanda-tanda perubahan yang muncul dan dihasilkan oleh tubuh, misalnya perbedaan level denyut nadi, jumlah keringat dan tanda-tanda kelelahan lainnya. Namun perubahan secara fisiologi yang dihasilkan akibat pengaruh suhu di luar tubuh kita cenderung tidak diperhatikan. Selama ini, saat berolahraga hal yang paling sering dilakukan untuk mengetahui kondisi tubuh kita adalah dengan cara menghitung denyut nadi, baik menggunakan cara manual yaitu palpase atau juga dengan menggunakan alat penghitung denyut nadi. Sejauh denyut nadi dalam kondisi normal atau telah memasuki zona nadi latihan (Training Zone), maka hal tersebut telah dianggap cukup untuk menunjukkan indikator kebutuhan latihan kita. Selain faktor tersebut, suhu lingkungan memiliki pengaruh besar pula terhadap fisiologi tubuh pada saat melakukan latihan olahraga. Seberapa besar pengaruh suhu lingkungan terhadap kondisi tubuh pada saat melakukan aktifitas olahraga. Dewasa ini tidak banyak namun terdapat beberapa referensi jurnal penelitian yang telah menyebutkan pengaruh suhu lingkungan terhadap kondisi tuubuh manusia dan pada kondisi apa suhu paling efektif dilakukannya latihan.

\section{METODE PENELITIAN}

Metode yang dilakukan ialah dengan melakukan review terhadap jurnal-jurnal penelitian yang ada, dikutip, didiskusikan dan 
disimpulkan untuk mendapatkan kesimpulan terbaik. Seluruh jurnal yang ada ialah yang saling berhubungan dengan pokok bahasan yang diangkat dalam artikel dan seluruhnya tercatat dalam sumber data dan daftar pustaka penelitian.

\section{KAJIAN PUSTAKA}

\section{a. Olahraga}

Olahraga memiliki pengertian kegiatan yang dilakukan untuk melatih tubuh manusia sehingga tubuh terasa lebih sehat dan kuat, baik secara jasmaniah mau pun rohaniah (Suryanto, 2012). Kegiatan olahraga yang dilakukan baik dalam intensitas yang ringan medium hingga berat, mampu meningkatkan suhu tubuh secara signifikan. Bagi orang awam, berolahraga mampu meningkatkan 15 kali lebih tinggi dari basal rate-nya, sedangakan bagi atlet dapat meningkatkan hingga 20 kali dari basal rate-nya

b. Suhu Tubuh

Suhu tubuh merupakan keseimbangan antara produksi panas dan kehilangan panas (Marie B dan Hoehn dalam McCallum, 2012). Jika tingkat panas yang dihasilkan setara dengan yang hilang, maka suhu tubuh ini akan stabil (Tortora dan Derickson dalam McCallum, 2012). Suhu tubuh manusia diatur dengan sistem umpan balik (feed back) yang diatur dalam sistem purat pengaturan suhu oleh hypotalamus. Jika suhu tubuh manusia terlalu tinggi, maka akan terjadi mekanisme umpan balik dengan cara mensekresi keringat ke permukaan tubuh, pembesaran pori-pori kulit dan stimulasi rasa haus.

Selain itu, suhu tubuh juga terpengaruhi oleh suhu lingkungan dan tingkat kelembaban udara. Semakin tinggi suhu udara, maka semakin tinggi pula tingkat kelembaban udara di sekitar. Efek yang dihasilkan oleh tingginya kedua hal tersebut mengakibatkan tubuh memberika stimulasi balik untuk melawan hal tersebut, salah satunya rasa haus yang muncul karena kehilangan cairan akibat sekresi keringat ke permukaan kulit sebagai proses pengaturan keseimbangan tubuh oleh hypotalamus.

Suhu tubuh manusia sehat, normalnya menurut beberapa penelitian sejak tahun 1972 yang dilakukan oleh Louis Eisman dalam Biology and Human Progress, Neil A Campbell, 1987:790, Louise Simmers, 1988, Mc Govern Celeste,1994 menyebutkan yaitu $37^{\circ}$ Celcius. Penelitian terbaru oleh Ziad Obermeyer, Jasmeet K Samra, Sendhil Mullainathan, 2017 menyebutkan bahwa suhu tubuh manusia dalam keadaan sehat yaitu $36.6^{\circ}$ Celcius.

Kadar air dalam tubuh manusia juga berpengaruh terhadap performa tubuh pada saat melakukan kegiatan. Persentase air dalam tubuh manusia sehat menurut H.H. Mitchell dalam Journal of Biological Chemistry, 158, menyebutkan bahwa otak dan jantung $73 \%$ dari volumenya merupakan air, paru-paru $83 \%$, Kulit $64 \%$, otot dan ginjal $78 \%$ dan tulang pun terdiri atas $31 \%$ air dalam keseluruhan komposisinya masing-masing. Selain itu, menurut Dr. Jeffrey Utz, dalam artikel "USGS, The USGS Water Science School" menyebutkan bahwa setiap tubuh manusia terdiri datas air dengan jumlah yang berbeda. Laki-laki dewasa terdiri atas $65 \%$ air dan wanita dewasa $55 \%$ air.

\section{c. Suhu Lingkungan}

Suhu lingkungan ialah tingkatan derajat panas atau dingin yang berlaku dalam ruang sekitar. Suhu ini dapat diukur dengan menggunakan alat thermometer. Suhu lingkungan erat kaitannya dengan tingkat kelembaban udara. Semkain tinggi suhu lingkungan maka semakin tinggi pula tingkat kelembaban udara di sekitar. 


\section{d. Suhu Kelembaban Udara}

Kelembaban udara ialah tingkatan kadar air dalam udara dalam bentuk uap air. Kandungan air dalam lingkungan dengan suhu yang tinggi, memiliki kadar yang lebih tinggi daripada kadar uap air dalam udara di lingkungan dengan suhu lebih rendah.

\section{e. Cairan Ludah}

Cairan pada ludah sedikitnya mengandung protein amilase, dan kortisol, dalam setiap perubahan fisiologis tubuh, terdapat perbedaan level kandungan yang terdapat pada cairan ludah.

\section{f. Asam Laktat}

Asam laktat merupakan residu dari pembakaran ATP dalam proses glikolisis. Proses tersebut dilakukan akibat kebutuhan energi pada saat tubuh mulai mengalami penurunan level supply oxygen demain. Sehingga untuk bisa meningkatkan proses penyuplaian oksigen dan pemenuhan energi, proses glikolisis terjadi.

\section{DISKUSI}

Suhu tubuh manusia sehat, normalnya menurut beberapa penelitian sejak tahun 1972 yang dilakukan oleh Louis Eisman dalam Biology and Human Progress, Neil A Campbell, 1987:790, Louise Simmers, 1988, Mc Govern Celeste,1994 menyebutkan yaitu $37^{\circ}$ Celcius. Penelitian terbaru oleh Ziad Obermeyer, Jasmeet K Samra, Sendhil Mullainathan, 2017 menyebutkan bahwa suhu tubuh manusia dalam keadaan sehat yaitu $36.6^{\circ}$ Celcius.

Suhu lingkungan berpengaruh terhadap kondisi tubuh manusia. Menurut Mi Hyun No, Hyo-Bum Kwak, 2016, menyebutkan bahwa oksigen yang dihirup tubuh pada saat latihan dalam intensitas sub-maximal dan maximal dan denyut nadi berada pada level yang lebih rendah jika melakukan latihan pada suhu lingkungan $22^{\circ}$ $\pm 1^{\circ}$ Celcius dari pada pada suhu $10^{\circ} \pm 1^{\circ}$ Celcius dan $35^{\circ} \pm 1^{\circ}$ Celcius. Selain itu kandungan asam laktat dalam darah juga lebih rendah dalam suhu tersebut baik pada saat jeda istirahat atau pada saat latihan. Hal tersbut berarti bahwa pada level suhu yang lebih rendah dari $22^{\circ}$ Celcius dan atau lebih tinggi, proses pengambilan oksigen kurang optimal, dan jumlah asam laktat yang dilepaskan akibat proses metabolisme lebih tinggi. Sehingga dengan kondisi tersebut, performa tubuh akan mengalami penurunan performa lebih cepat.

Kelembaban udara yang tinggi akibat dari tingginya suhu lingkungan juga mempengaruhi tingkat dehidrasi yang merupakan efek samping tingginya suhu tubuh sebagai bentuk penyesuai suhu tubuh terhadap lingkungan. Semakin tinggi kelembaban udara, tubuh menyesuaikan dengan cara memperbesar pori-pori kulit, dan juga mengeluarkan keringan lebih banyak sebagai bentuk penyesuaian suhu permukaan kulitdan juga suhu sekitar. Semakin tinggi suhu lingkungan, semakin banyak keringat yang dibutuhkan, maka semakin banyak pula air yang dibutuhkan untuk mengantikan sekresi keringat dari dalam tubuh. Apabila kondisi tersebut berlangsung cukup lama tanpa adanya tambahan cairan tubuh, kemungkinan besar yang terjadi ialah heat exhaustion, heat stroke, heat aesthenia dan bahkan terburuk serangan jantung.

Kelembaban udara yang tinggi juga memiliki efek yang buruk bagi tubuh pada saat berolahraga. Selain dampak yang tersebut di atas, suhu dan kelembaban tinggi juga meningkatkan resiko cedera lebih tinggi. Hal tersebut juga sebagai akibat dari dehidrasi yang tinggi, proses sekresi keringat yang banyak dan proses metabolisme dan distribusi aliran darah yang lebih cepat. Semakin tinggi metabolisme terjadi, perubahan fisiologi tubuh juga terjadi, sebagai efeknya, proses metabolisme (perubahan sistem energi) yang meningkat juga akan meningkatkan asam laktat pada otot, sehingga, semakin cepat pula kelelahan pada otot dan tubuh. Apabila hal 
tersebut berlangsung dalam waktu yang lama tanpa disadari oleh manusia, yang terjadi yaitu kram otot (kejang) dan penurunan performa.

Kenaikan suhu tubuh yang terlalu cepat juga berpengaruh terhadap kadar air dalam tubuh manusia, semakin tinggi suhu tubuh sebagai akibat proses metabolisme pada saat latihan, maka semakin banyak pula residu air berupa keringat yang dibuang melalui kulit kita. Julien $D$ Periard, Gavin J.S. Travers, Sebastien Racinais, Michael N Sawka, 2016, menyebutkan bahwa selama aktifitas latihan darah terpompa lebih cepat sebagai akibat suhu permukaan kulit meningkat yang diiringi pula peningkatan suhu pada otot-otot tubuh, darah dialirkan lebih cepat sebagai bentuk penanggulangan akibat meningkatnya suhu, selain suhu tersebut meningkat akibat proses metabolisme dan proses perubahan energi. Untuk mengatasi hal tersebut tubuh melakukan Cardiovasculer adaptations dengan cara membutuhkan kadar air dalam tubuh yang lebih banyak, salah satunya stimulasi rasa haus yang terjadi. Selain itu ukuran plasma sel dalam tubuh mengalami perkembangan, penurunan jumlah nadi per menit, peningkatan efisiensi otot, dan peningkatan kecepatan aliran darah dan respon kulit untuk berkeringat lebih cepat.

Penelitian lain menyebutkan, Romeu P. et al.(2018), dalam suhu yang berbeda, $40^{\circ}$ Celcius dan $22^{\circ}$ Celcius, setelah melakukan exercise, kandungan amilase pada cairan ludah tidak terdapat peningkatan, namun, pada denyut nadi terdapat kenaikan serta peningkatan kandungan kortisol pada cairan ludah, kandugan konsentrasi protein serta peningkatan asam laktat. Chicarro JL et. Al. (1998), menyebutkan juga bahwa kandungan cairan ludah, amilase, dan elekrolit $(\mathrm{NA}+)$, mengalami peningkatan setelah dilakukan olahraga

Prabhjot Saini, Sandeep kaur, Bindu K, Jasbir Kaur, 2014 menyebutkan pada penelitiannya terhadap sampel yang dipilih tanpa melakukan aktifitas berat menyebutkan bahwa perubahan suhu tubuh terendah terjadi pada suhu lingkungan $20^{\circ}$ Celcius dan pada suhu normal ruangan $\left(27^{\circ} \mathrm{C}\right)$ serta $30^{\circ}$ Celcius peningkatan suhu tubuh pada mulut dan bagian lipatan tubuh lebih tinggi.

Kadar air dalam tubuh manusia juga berpengaruh terhadap performa tubuh pada saat melakukan kegiatan. Persentase air dalam tubuh manusia sehat menurut H.H. Mitchell dalam Journal of Biological Chemistry, 158, menyebutkan bahwa otak dan jantung $73 \%$ dari volumenya merupakan air, paru-paru $83 \%$, Kulit $64 \%$, otot dan ginjal $78 \%$ dan tulang pun terdiri atas 31\% air dalam keseluruhan komposisinya masing-masing. Selain itu, menurut Dr. Jeffrey Utz, dalam artikel "USGS, The USGS Water Science School" menyebutkan bahwa setiap tubuh manusia terdiri datas air dengan jumlah yang berbeda. Laki-laki dewasa terdiri atas $65 \%$ air dan wanita dewasa $55 \%$ air.

Keseluruhan proses peningkatan suhu lingkungan, kelembaban udara dan suhu tubuh, sangat berpengaruh terhadap tingkat dehirasi tubuh. Jika hal tersebut dibiarkan dalam jangka waktu yang lama, tubuh bisa mengalami beberapa kondisi seperti yang tersebut di atas, yaitu heat exhaustion, heat stroke, heat aesthenia dan bahkan terburuk serangan jantung. Heat exhaustion memberikan dampak kelelahan yang tinggi, dapat disertai rasa mual dan pusing, hal ini sebagai bentuk awal dari dehidrasi cairan tubuh. Tingkatan yang lebih tinggi, yaitu heat stroke berlaku kondisi yaitu hilangnya kesadaran disertai mengigau, koma dan bahkan meninggal dunia sebagai akibat terlalu tingginya suhu yang memapar otak secara berlebih. Heat aesthenia memberikan dampak jenuh, pusing, mudah tersinggung atau marah, kurangnya nafsu makan, hingga insomnia. 


\section{SIMPULAN DAN REKOMENDASI}

Berdasar pada diskusi di atas diketahui sejauh ini bahwa suhu lingkungan pada kisaran $20^{\circ}$ $-23^{\circ}$ Celcius merupakan suhu yang optimal terhadap VO2Max (Oxygen Intake/ pengambilan oksigen) dan kadar asam laktat dalam darah apada saat jeda istirahat serta pada saat aktifitas. Selain itu, proses dehydrasi, kecepatan aliran darah, dan sekresi keringat semakin meningkat pula sesuai dengan peningkatan suhu tubuh sebagai bentuk peningkatan metabolisme dan perubahan energi, serta sebagai bentuk proses penekanan terhadap suhu tubuh yang tinggi

Keseluruhan proses peningkatan suhu lingkungan, kelembaban udara dan suhu tubuh, sangat berpengaruh terhadap tingkat dehirasi tubuh. Jika hal tersebut dibiarkan dalam jangka waktu yang lama, tubuh bisa mengalami dehidrasi, heat exhaustion, heat stroke, heat aesthenia dan bahkan terburuk serangan jantung.

\section{REFERENSI}

Campbell, Neill A. Abiology, 3rd ed. California: Benjamin Cummings, 1987:790.

Chicarro J.L. et. Al. 1998. Saliva Composition and Exercise. Sports Medicine, Vol 26, 17-27.

Eisman, Louis. Biology and Human Progress. Englewood Cliffs, NJ: Prentice Hall, 1972:125. Jiexieu Zhao et.al. 2013. Effect of Heat and Different Humidity Levels on Aerobic and Anaerobic Exercise Performance in Athletes. Journal of Exercise Science \& Fitness, 11:3541.

McGovern, Celeste. "Snatched From an Icy Death". Alberta Report/Western Report. Academic Abstract: United Western Communication, 1994:2.

MiHyun No, Hyo-Bum Kwak. 2016. Effects of enviromental temperature on physiological response during submaximal and maximal exercise in soccer players. Integrative Medicine Research, 5:216-222).
Prabjhot Saini, Sandeep Kaur, Bindu K, Jasbir Kaur. 2014. Effect of Controlled Room Temperatureon Oral and Axillary Body Temperature Among Healthy Young People. Nursing and Midwifery Research Journal, Vol 10:4.

Romeu P et al. 2018. The Influence of a Hot environment on Physiological stress Responses in Exerceise until Exhaustion.PONE Journal.

Simmers, Louise. Diversified Health Occuptions. 2nd ed. Canada: Delmar:150-151.

Temperature, Body. "World Book Encyclopedia" 2nd ed. Chicago: Field Enterprises, 1996.

Ziad Obemeyer, Jasmeet K Samra, Sendhil Mullainathan. 2017. Individual Differences in Normal Body Temperature: Longitudional Big Data Analysis of Patient Record. BMJ: 359 